Cahiers $d u$ MONDE RUSSE

\section{Cahiers du monde russe}

Russie - Empire russe - Union soviétique et États indépendants

$52 / 4 \mid 2011$

Varia

\title{
Rodolphe Baudin, Nikolaï Karamzine à Strasbourg
}

\section{Gerda S. Panofsky}

\section{(2) OpenEdition \\ Journals}

\section{Electronic version}

URL: http://journals.openedition.org/monderusse/7514

DOI: 10.4000/monderusse.7514

ISSN: $1777-5388$

Publisher

Éditions de l'EHESS

\section{Printed version}

Date of publication: 20 December 2011

Number of pages: $677-680$

ISBN: 978-2-7132-2353-2

ISSN: $1252-6576$

\section{Electronic reference}

Gerda S. Panofsky, « Rodolphe Baudin, Nikolaï Karamzine à Strasbourg », Cahiers du monde russe [Online], 52/4 | 2011, Online since 18 January 2013, Connection on 25 September 2020. URL : http:// journals.openedition.org/monderusse/7514; DOI : https://doi.org/10.4000/monderusse.7514

This text was automatically generated on 25 September 2020 


\title{
Rodolphe Baudin, Nikolaï Karamzine à Strasbourg
}

\author{
Gerda S. Panofsky
}

\section{REFERENCES}

Rodolphe BAUDIN, Nikolaï Karamzine à Strasbourg. Un écrivain-voyageur russe dans l'Alsace révolutionnaire (1789). Presses Universitaires de Strasbourg, 2011, 321 p., 30 ill. (Études orientales, slaves et néo-helléniques)

1 Baudin presents a marvellous wealth of little or unknown sources, literary as well as pictorial, illustrating the history and culture of the Alsace during the period of the Enlightenment. In a narrower sense, his book could be defined as an hommage to Strasbourg. Its emphasis is on the revolutionary turbulences of the year 1789, in which the young Russian traveller Nikolai M. Karamzin was briefly confronted with them. Karamzin's Bildungsreise and the resulting Pis'ma russkogo putešestvennika are set in the tradition of eighteenth century travel literature and in particular within the longstanding Russian ties to France (and Strasbourg). In addition, Baudin's "texte strasbourgeois" is enhanced by several interesting excursuses (on the Pugachev revolt, the writing on trees, the "tourisme des chambres"). The culmination of the book is the far-reaching discourse (Chapter VII, 2-4) on Karamzin's appreciation of the Gothic versus the Baroque and Classicist ("Greek") style in architecture and sculpture, comments that were elicited by his Strasbourg impressions.

2 According to his Letter 46, in 1789 Karamzin spent a single day in Strasbourg, arriving at 7 p.m. on 5 August and leaving at 6 a.m. on 7 August. As he narrates, he visited the Münster and the Church of St.-Thomas, where he inspected the tomb of the Maréchal de Saxe, was shown the University with its anatomical theatre and medicinal herb garden, and in the evening attended a play. If one adds his travel routines of finding a barber and a man-servant as cicerone, the reserving of the stage-coach to Switzerland (to be paid in advance, Letter 47), and the expressly mentioned obed and užin in company, he 
could not reasonably have accomplished more in those few hours. Baudin deconstructs Karamzin's account. While in Chapter IV, which deals with Karamzin's Strasbourg stay proper, the conjunctive mood, and the words possible, probable, sembler / vraisemblable, most of all peut-être abound, in the following sections of the book the "hypothèse" turns into certainty, if not the idée fixe: Karamzin was never present at any of the sites and events that he describes, but in point of fact took the plentiful details from printed travelogues and engravings.

If Karamzin enriched the published version of the Pis'ma with common data, it does not imply that he never set foot into those buildings! Baudin wonders for instance, how his protagonist could have spotted the Russian graffiti among the numerous tourists' scribbles high up on the Cathedral tower. As they lack signatures, he discards them as " douteuses". If indeed Strasbourg attracted so many Russians, would the guides, greedy for a tip, not have pointed out the Cyrillic inscriptions to them (as English ones to Englishmen)? Maybe Karamzin's countrymen left only their initials, - what need to record them. As for the other monuments, Baudin demonstrates at great length, how on the $6^{\text {th }}$ of August mutinous drunken soldiers were molesting the citizens in the streets of Strasbourg, wherefore it was "fort possible" that the churches had been shut. Never mind that Karamzin reports "no žiteli zatykajut uši i spokojno otpravljajut svoi dela" and at the theatre "krome veselosti, nichego ne primetil na publike". Obviously the rabble was noisy and annoying, but not blood-thirsty and life-threatening. The army officers laughed at the commotion out of the window, watching it like a "spectacle" all right, but like a "carnaval" (Chapter V, 1) in August? The theatre metaphors (Chapter V, 2), we may add, go back to antiquity and ever since Calderón's “theatrum mundi” had become a topos. ${ }^{1}$

4 If circumstances prevented Karamzin from enjoying sightseeing, e.g. the "Last Judgment" altar-piece in Danzig or the Neue Palais in Potsdam (Letters 10, 17), he would say so. He would also state his regret, if he missed a celebrity, as for example Trendelenburg, Goethe, above all Starck (Letters 10, 33 f., 42). Thus there is no reason to ponder, whether he might or might not have paid his respects to Louis-Claude de Saint-Martin or Jean Hermann, if he never intended to do so. Baudin seeks out "silences " or "absences", - to wit the title of the theatre piece (which incidentally is also twice not related in Frankfurt, Letter 42), the aforesaid signatures under the Russian graffiti, Karamzin's entry in the golden guest-book of the Natural History Museum, the name of the amiable master, who accompanied him, etc. Very suspicious appears to Baudin that Karamzin failed to identify the Strasbourg hotel, where he slept two nights. Evidently he wanted "brouiller sa piste", for as a "règle stricte" he always supplied the name of his inn. He certainly did so in Berlin (plus street address, landlord, guests, as well as prices for room and board), ${ }^{2}$ but Mainz would be another exception to the rule (not just Mannheim and Strasbourg, p.125). Slightly chauvinistic, Baudin generally ignores Karamzin's experiences in Germany and depreciates all things German. Quite the reverse, Karamzin loved to talk in German, which he spoke fluently (Letters 4, 34), and he wrote German - in German script - flawlessly (various autographs). When Karamzin alighted at a certain town for a week or so as in Berlin, Leipzig, or Frankfurt, let alone for more than five months as in Geneva, he tells the reader, where he lived. However, on the road he contented himself to rest overnight at the posting-station, where the horses were changed. Thus en route to Dresden or Frankfurt (Letters 22, 38), and in Dresden itself he "ostanovilsja $v$ traktire na pochtovom dvore" (Letter 23). Most probably this was the case in Mainz too (Letter 43), as he was continuing with the same "diližans". 
Did Karamzin then check into any of the Strasbourg hotels that Baudin (p.126f.) recommends? Since Strasbourg was only a stopover on the way to Basel, given the early departure at 6 o'clock next morning, might he not have "posé son bagage" at the postingstation?

Baudin draws the conclusion that at whichever lodgings Karamzin had put up, he passed the day nervously holed up in his room and never ventured outside. Sure, in the lawless countryside (but not in a fortified town) Karamzin feared to get robbed of his gold coins, as he shuddered about the triple murder near Oranienburg (Letters 8, 14), felt vulnerable in the dark woods near Potsdam (Letter 17), and was apprehensive about brigand-ridden Alsace (Letter 47).

Baudin (p. 31 f., 82) is heavily indebted to Yuri Lotman's schizophrenic concept of the author's split personality into two travellers, one fictional and one real. ${ }^{3}$ Throughout his book "le narrateur karamzinien" and "Karamzine lui-même" are moving in tandem like Siamese twins. Although Lotman's speculation of Karamzin's covert trip to Paris to join his freemason friend $\mathrm{A}^{*}$ alias Kutuzov would have suited Baudin's analysis, recent archival findings do no longer allow this escapade. ${ }^{4}$ Yet Baudin (p. 124 ff.) offers a new likewise unfounded - conspiracy theory: Karamzin did not hurry to Paris, but instead Kutuzov was rushing back to Strasbourg, where the two men had a secret "rendez-vous" (which would answer the question on p. 120: if he avoided going to places of interest," que Karamzine a-t-il donc fait à Strasbourg?"). Let us get this straight: after Karamzin's hopes were dashed to meet Kutusov still in Berlin at the end of June, three weeks later in Leipzig (Letter 32) he received two pieces of mail from $A^{*}$ about to leave for Paris " $n a$ neskol'ko nedel'", asking to await him either at Mannheim or at Strasbourg (i.e. by mid August). Karamzin lamented, "no mne nikak nel'zja ispolnit' ego želanija. Takim obrazom razrušilos' to zdanie prijatnostej i udovol'stvij, kotoroe osnovyval ja na svidanii s ljubeznym drugom! " and "Grustno mne, očen' grustno, čto ja ne uvižus's $A^{* ”}$ (both passages left out by Baudin). As Karamzin would definitely travel over Mannheim and Strasbourg, it can only mean that Kutuzov's dates did not fit into his itinerary. Kutuzov does not seem to have suggested a compromise, since Karamzin was disappointed not to find any message from him in Strasbourg, "Ja nadejalsja zdes' najti pis'mo ot $A^{*}$, no ne našel" (this phrase is also not quoted by Baudin, except that it is contained in the full transcript of Letter 46 in French and Russian in the Appendix).

7 To sum up, as thanks to his admirable archival and library research Baudin brilliantly succeeds in painting not only a lively and colorful, but also highly sophisticated panorama of eighteenth century Strasbourg, especially the city's image in the eyes of contemporary Russians, - why his obsession to debunk Karamzin's Pis'mo 46 as a mere “ supercherie littéraire"?

\section{NOTES}

1. Ernst Robert Curtius, Europäische Literatur und Lateinisches Mittelalter, Bern, 1948, p. 146-152. 
2. Gerda Panofsky, Nikolai Mikhailovich Karamzin in Germany: Fiction as Facts, Wiesbaden: Harrassowitz, 2010, p. 77-84; also ead., "Priezd Karamzina v Berlin i ego vstreča s russkim veteranom v Potsdame," XVIII vek, 26, 2011, p. 254-287, esp. p. 254-261.

3. Ju.M. Lotman, Sotvorenie Karamzina, M.: Kniga, 1987.

4. Svetlana Gellerman, "Karamzine à Genève," in Monika Bankowski, ed., Fakten und Fabeln: Schweizerisch-slavische Reisebegegnung vom 18. bis zum 20. Jahrhundert, Basel - Frankfurt am Main: Helbing \& Lichtenhah, 1991, p. 71-90, esp. p. 85. 